\title{
Könyvtárzöldítés: környezettudatosság alakítása-erősítése hagyományos és nem hagyományos könyvtári eszközökkel
}

\section{A tatabányai József Attila Megyei és Városi Könyvtár ökológiai szemléletü tevékenységeiről"}

Az ipari forradalmakat követően, de föleg az 1950-es évektől tekintve az emberiség sokirányú tevékenységeinek hatására olyan jelentős környezeti, ökológiai változások következtek be, amelyek visszavonhatatlanul megváltoztatták bolygónk arculatát és erőforrásainak megújító képességeit. Bár nem hivatalos és tudományos, de már a köztudatban használt kifejezéssel ezt a korszakot Antropocénnek, azaz az Ember Korszakának is hívhatjuk a fentiek miatt, s még használatosak a 4. ipari forradalom, az E(lektronikus) korszak, a Digitális világkorszak elnevezések is. Mindenesetre nemcsak látható, de a saját bőrünkön is tapasztalható változások lényege az, hogy a mértéktelen földhasználat súlyos következményeivel kell szembesülnünk: megváltoztak a földrészeket érintő időjárásminták, a tengerszintek megemelkedtek, a fuldokló és élhetetlen nagyvárosok tömegszívó hatása drasztikusan felerősödött, valamint a civilizációs melléktermékként keletkező, szinte már kezelhetetlen hulladékhalmok mindenhol visszaszorítják a növény- és életvilág élettereit. A fogyasztóiság ösztönzése, a globalitás egyre szélesebbre nyíló szociális ollója mind oka lehet egy olyan világképnek, amely elidegeníti az emberi entitást a természetességétől, amely így létének lényegét tekintve a fenntarthatatlanság helyzetébe sodródik. Éppen ezért a technika robbanásszerü fejlődése nem áldásként jelentkezik, hanem párhuzamosan, ahogy néhány szakember használja, „varázstalanítja”, „lelkiségétől megfosztja" világunkat. Bár egymást érik a fenntarthatósággal kapcsolatos nemzetközi konferenciák, tanácskozások, programtervezetek, a globális felmelegedés rémisztő képe mégis érződik már az emberiség minden életterületén, így a gazdaság, a társdalom, a kultúra, a jólét, az egészség aspektusaiban egyaránt.

Mi következhet ezekböl? Alkalmazkodni és cselekedni kell, mert nem dughatjuk fejünket a homokba, hogy valaki megoldja helyettünk a problémát. Összegezve: korunk egyik legnagyobb kihívása a környezeti állapotunk harmóniájának,

* Könyvtárzöldítés: librarygreening avagy a Környezeti nevelés, környezettudatosság alakítása/erösítése: Hagyományos és nem hagyományos könyvtári eszközökkel. A tatabányai József Attila Megyei és Városi Könyvtár ökológiai szemléletü tevékenységeiről címü pályázatunkat, amelyet az IFLA Zöld Könyvtár Díj pályázati felhívására adtunk be és jelentős mértékben az ELTE Központi Könyvtárában tartott prezentációnkat tartalmazta, a világ legjobb hat pályázata közé választották, és végül második helyezést ért el. 
önmegújító, öngyógyító képességének megbomlása. 2017. augusztus 2-ára datálták ebben az évben az Ökológiai Túllövés Napját. Ebben az évben eddig tart a bolygó éves energiamegújító képessége, a többit a jövőből vesszük el. Megjegyzem, 2010-ben ez a dátum még augusztus 20-ára esett.

Tehát alkalmazkodás és cselekvés várható el az élet minden szereplőjétől, akár egyedi, akár társadalmi szinteken, így a könyvtáraktól is. Egy új paradigmára, fenntarthatósági nézőpontra van szükségünk, amely átfogja a tevékenységünk minden részterületét, és egyfajta zsinórmértékül szolgál a munkánkban.

Nem is olyan régen a magyar könyvtáros társadalom egyik megmozdulásának a jelszava ez volt: Könyvtárak összefogása a társadalomért. A könyvtáraknak mint információs intézményeknek és rendszereknek sajátos eszközeikkel (és használva az elektronikus-digitális módszereket), kiterjedési mátrixukkal megvan a lehetőségük, hogy a környezettudatosítás élére állhassanak. Nem árt hangsúlyozni azt sem, hogy ezzel a rólunk alkotott, megkopott társadalmi képen és ,a könyökvédős", nehezebben mozduló beállítottságukon is tudunk változtatni, az általunk létrehozott hasznosulási értékek mellett.

Leggyorsabban a helyi válaszok, intézkedések, személyes és akár intézményes példák hathatnak, így a könyvtárak is, amelyek információkat, dokumentumokat gyüjtenek, dolgoznak fel, rendszereznek és adnak közre. A közösségiközmüvelödési könyvtárak nyilvánosságukkal a társadalom minden szereplöjét, rétegét elérik. A megoldások segítése már mindenkit érint, így a könyvtárakat is, amelyeknek napjainkban egyik kiemelt feladata, jelentős szerepe lehet a környezettudatosítás erősítésében, mert a klímaváltozás, a környezeti harmónia felbomlása, ökológia állapotunk, helyzetünk romlása - mint életfeltételünk nélkülözhetetlen alapja - érinti a bolygó egész lakosságát. Ennek okán a könyvtáraknak ugyanakkor a saját hagyományos feladatrendszerük és szolgáltatásaik mellett egy új, környezetmegújító paradigma, vezérfonal irányában kell megtalálniuk az új szerepüket. Ennek egyik eleme a helyi körülményeket figyelembe vevő, naprakész ökológiai-dokumentációs-információs rendszer kialakítása lehet. A helyi kezdeményezések és példák hathatnak a leggyorsabban.2010-ben a tatabányai József Attila Megyei és Városi Könyvtár új vezetése, dr. Voit Pál igazgatóságával kezdődően, a közösségi közművelődési könyvtárak közül elsőként vette küldetésnyilatkozatába kiemelt feladatként ezt a szolgáltatást. Az év nyarától kezdte kialakítani az ökológiai tájékoztató részleget, az információs szolgáltatórendszert, amely jelenleg már nem korlátozódik az anyakönyvtárra, hanem a fiókjaira, sőt a tőle szolgáltatást rendelő kistérségek kisebb könyvtáraira is kiterjed.

Könyvtárunk szellemiségének, filozófiájának egyik pillérét az intézményünk által a küldetésnyilatkozatunkban közzétett ökológia elkötelezettségünk és társadalmi felelősségvállalásunk képezi. Idézem ennek második pontját: „Az ökológiai gondolkodás, a környezettudatosság terjesztése, erre való szemlélet- 
formáló nevelés, programok szervezése, a környezeti információk kiemelt gyüjtése és ezekből való szolgáltatás".

Könyvtárunk 2010-től a szakmai lehetőségein keresztül tudatosan törekszik egy nyilvános, közművelődési, zöld könyvtár létrehozására, melyben sarkalatos társadalmi felelösségvállalásként, feladataként tartja szem elött a vonzáskörzetének, valamint a megyénk kistérségeinek a környezeti nevelését, természeti értékeinek megismertetését. Így napjainkban a környezetismereti-környezetnevelési tevékenységünk, amelyet egyre elhivatottabban folytatunk már hetedik éve, szerves részét képezi a sokrétü, hagyományos és nem hagyományos könyvtári munkánknak. Ma már elmondhatjuk, hogy egyre nagyobb érdeklődés és nyilvánosság kíséri (könyvtári és ökológiai szakértők által is) az egymásra épülő, egymást kiegészítö ökológiai munkánkat. Több ezer kötetes ökosarkunk, ökoesték rendezvénysorozatunk, online öko-hírlevelünk és öko-cikktárunk, helyi és országos ökorendezvényeken való megjelenésünk, a fiókjaink és kistérségeink zöldpolc-rendszerének kialakítása, valamint kiadványunk-összefoglalónk ebbéli tevékenységünkről és a nyári zöld olvasótermünk mellett megjelenünk az iskolai időn kívüli, az oktatást és nevelést segítő környezetnevelési programjainkkal, mint az ökoolvasótáboraink megszervezése és a gyermekkönyvtárunk ökofoglalkozásai, -táborai, -rendezvényei is munkánkat színesítik és gazdagítják.

Környezettudatosító tevékenységünk minden egyes munkaterületünkön jelentkezik, és a városi, regionális, megyei hatókörön túl már országos és nemzetközi megmérettetésünk is van. Ebbéli munkánk érinti az állományalakítás, -elhelyezés, adatbázis-építés, közösségfejlesztés, előadások, iskolán kívüli oktatás, honlapépítés, határon túli kapcsolatok részterületek mellett még számos szakmai tevékenységünket. Komplex ökológiai munkánkat $A$ tatabányai Ökokönyvtár Az ökológiai gondolkodás erösitése Tatabánya város lakóközösségében könyvtári eszközökkel címü kiadványunk alapján foglaltam össze, amely a honlapunkon (www.jamk.hu) A Fenntartható jövőért rovatunkban megtalálható letölthető formában, már angol nyelven is. ${ }^{1}$

Összefoglalva könyvtári-környezettudatosító munkánk részterületeiröl adok a továbbiakban számot.

\section{Ökotevékenységünk részterületeiről röviden: hagyományos és nem hagyományos könyvtári tevékenységek}

\section{A Fenntartható jövőért}

Honlapunkon A Fenntartható jövöért menüben (http://www.jamk.hu/?q=hu/ okojamk) megtalálható könyvtárunk összes ökoszolgáltatása: a havi rendsze-

${ }^{1}$ L. http://www.jamk.hu/letoltesek/agora_cikk/Okofuzet_A5_interaktiv.pdf (2017. szeptember 28.). 
rességgel megjelenő öko-hírlevelek, az öko-cikktár válogatott bibliográfia, az ökofüzet, fotógalériák, cikkek a könyvtár ökotevékenységeiről és könyvbemutatóiról, írások, rendezvények, ajánlók és az MTI Környezetvédelmi Hírlevele.
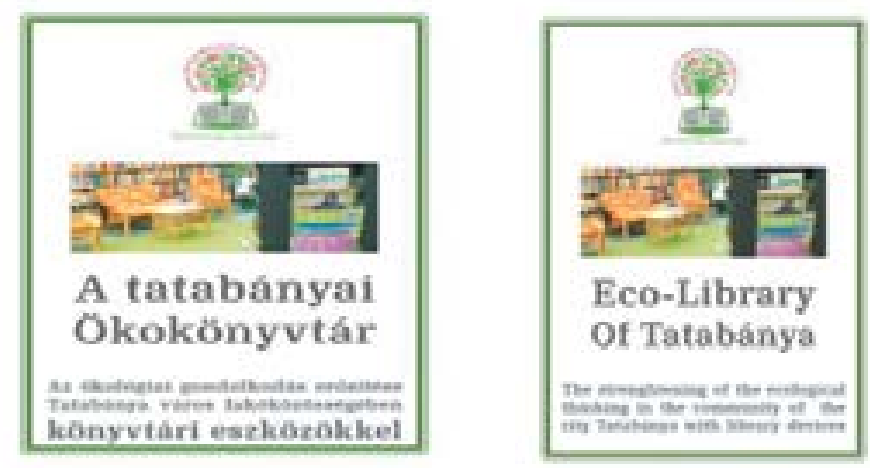

1. ábra. A tatabányai Ökokönyvtár

\section{Ökosarok-ökotéka (2010-)}

Ökosarokként külön kis olvasótér lett kialakítva a könyvtáron belül. A tágabban értelmezett ökológia témaköreiből a jelenlegi kínálat mintegy 7000 kötet könyv és 30 folyóirat. Ebből kb. 1500 kötet a szabadpolcon is megtalálható. Könyvválasztékunk nemcsak a kimondottan természettudományos munkákat tartalmazza, hanem a más tudományterületek ökológiát érintő, keresztező alkotásait is.

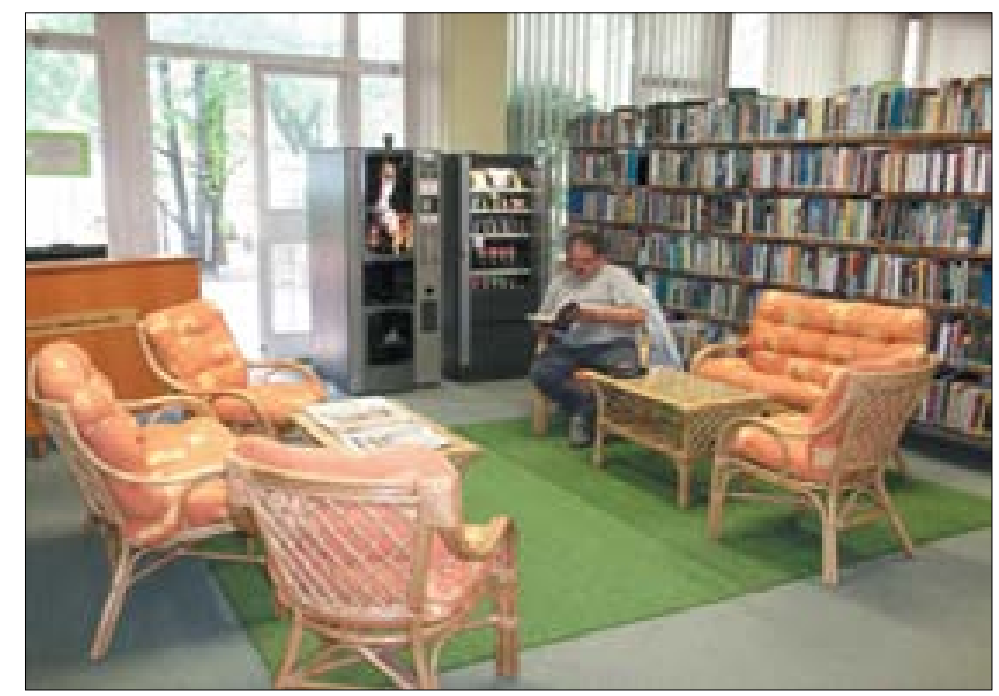

2. ábra. Ökosarok - ökoolvasótér 


\section{Öko-hírlevél / Öko-hírek (online) (2011-)}

Témakörei: Fenntartható fejlődés - Környezettudatosság - Környezetvédelem Humán ökológia - Együttéléstan - Alternativ és megújuló energiák - Planetáris és kozmikus tudatosság. Cikkek, tudósítások, saját és külső riportok ökorendezvényeinkről. Könyv- és videoajánlók, folyóirat-ajánlók fókuszában mind-mind a fenntarthatóság áll. Az Öko-linkek rovatunk a világ, hazánk, lakóhelyünk környezeti állapotáról, természeti értékeinkről, környezetvédelmi megoldásokról, a megújuló energiák használatáról, a technikai újdonságokról, találmányokról kínál válogatást.

2011-től az ökológia témaköréből havonta jelenik meg összeállítás időszerü és érdekes cikkekkel, írásokkal, ajánlókkal, programjaink népszerüsítésével hírlevél formában.

Mára már kinőttük a hírlevél formát, és egyre inkább egy havonta megjelenő online hírösszefoglalóra-ajánlóra kezdünk hasonlítani. Hírleveleinket több száz címre tudjuk kiküldeni e-mailen keresztül is. 2011 óta mintegy 1000, az interneten elérhető cikket, tanulmányt ajánlottunk fel elérhetőségükkel, és mintegy 80 saját és külső, a környezettel kapcsolatos rendezvényről tudósítottunk.

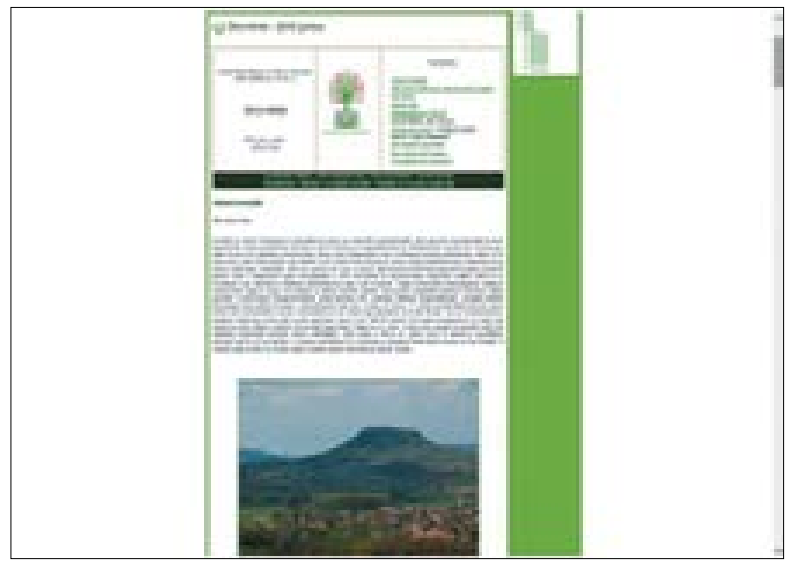

3. ábra. Öko-hírek online

\section{Öko-cikktár, ajánló bibliográfia (online, 2015-)}

2015 februárjától új elemként jelentkezik az Öko-cikktár, amely a könyvtárban előfizetett napilapok és folyóiratok környezettudatos írásaiból válogat. Ez tulajdonképpen egy annotált, rövid tartalmi összefoglalót, kivonatokat tartalmazó ajánló-cikkbibliográfia. A 2015-ös cikkajánlóhoz tárgymutató is készült, hogy segítse azokat, akik az egyes ökológiai témákban el szeretnének mélyülni. 2017 nyaráig megközelítőleg 650 cikket dolgoztunk és tártunk fel. A téma iránti érdeklődőket tárgymutató segítheti az eligazodásban. 


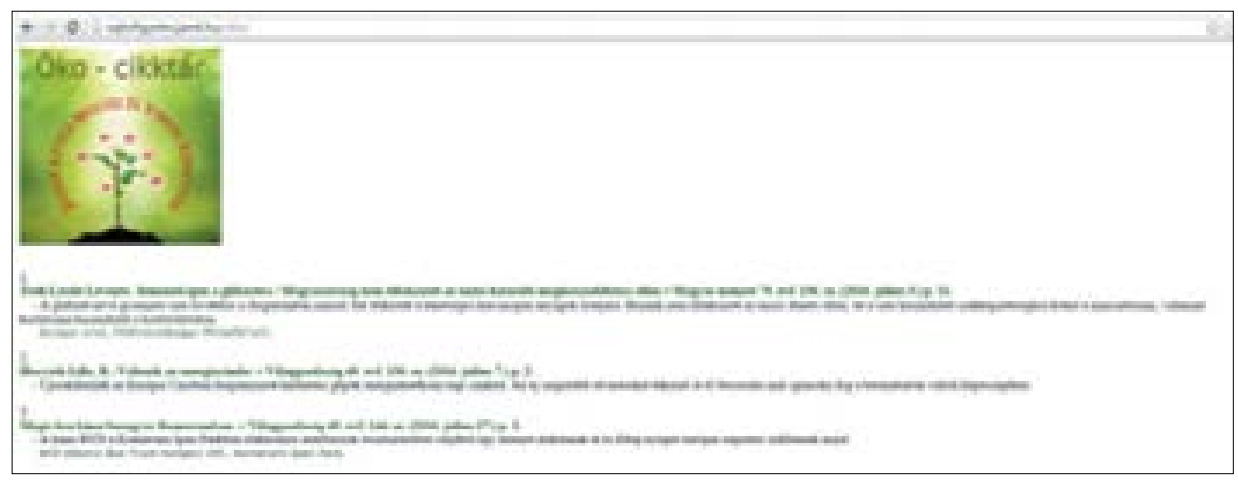

4. ábra. Az öko-cikktár és elérhetősége: http://sajtofigyeles.jamk.hu/oko

\section{Öko-esték előadássorozat (2010-)}

Az Öko-esték rendezvénysorozat 2010 októberétől havonta megrendezett elöadássorozat a fenntarthatóság, a megújuló energia, a környezetvédelem, a környezeti nevelés, az együttéléstan, a környezettudatosság erősítése érdekében. 2017 közepéig 70 előadást tartottuk meg. Az Öko-esték célja, hogy hazai és helyi szakértők tolmácsolásával felhívjuk a vonzáskörzetben élők figyelmét a környezet- és természettudatosságra, a fenntartható fejlődés lehetőségeire. Az Öko-esték előadóinak kiválasztásában arra törekedtünk, hogy a társadalom szereplőinek minél szélesebb köréből hívjunk meg előadókat, minél sokrétübben, ha tetszik, holisztikus megközelítéssel adjunk közre véleményeket, javaslatokat, megoldási lehetőségeket, látképeket jelenlegi környezeti helyzetünkről és az azokat ért károk orvoslásáról. Nem a teljesség igényével: ökológusokon kívül homeopata gyermekorvos, fizikus, spirituális kutató, író, dramaturg, zenepedagógus, gombaszakértő, ökoépítész, könyvtáros, újságíró, természetgyógyász, humánökológus, zenész, orvosprofesszor, akvarista, országgyülési képviselő, kutatómérnök, régész, előadóművész, minisztériumi főosztályvezető, képzőművész, magyarságkutató, gépészmérnök, biológus-tanár, zarándokegyesület, a Tudatos Vásárlók Egyesülete, muzeológus, futóegyesület, kertészmérnök, grafológus, újságíró, jógaoktató, fotóművész, amatőr csillagász, gyógytestnevelő, karateoktató, barlangász, agrármérnök, tibeti mester, geológus, sportmenedzser, kutatóintézet vezetője, középiskolai tanár szemszögéből közelítettük meg a témát.

Az Öko-esték sorozatunk korai időszakáról könyvtárunk 2014-es évkönyvében ${ }^{2}$ is beszámoltunk.

${ }^{2}$ Nász János: Fenntarthatóság és ökológiai szemlélet: Öko-esték a József Attila Megyei és Városi Könyvtárban 2010-2013. = In: A József Attila Megyei és Városi Könyvtár Évkönyve, 2014. 46-61.p. 


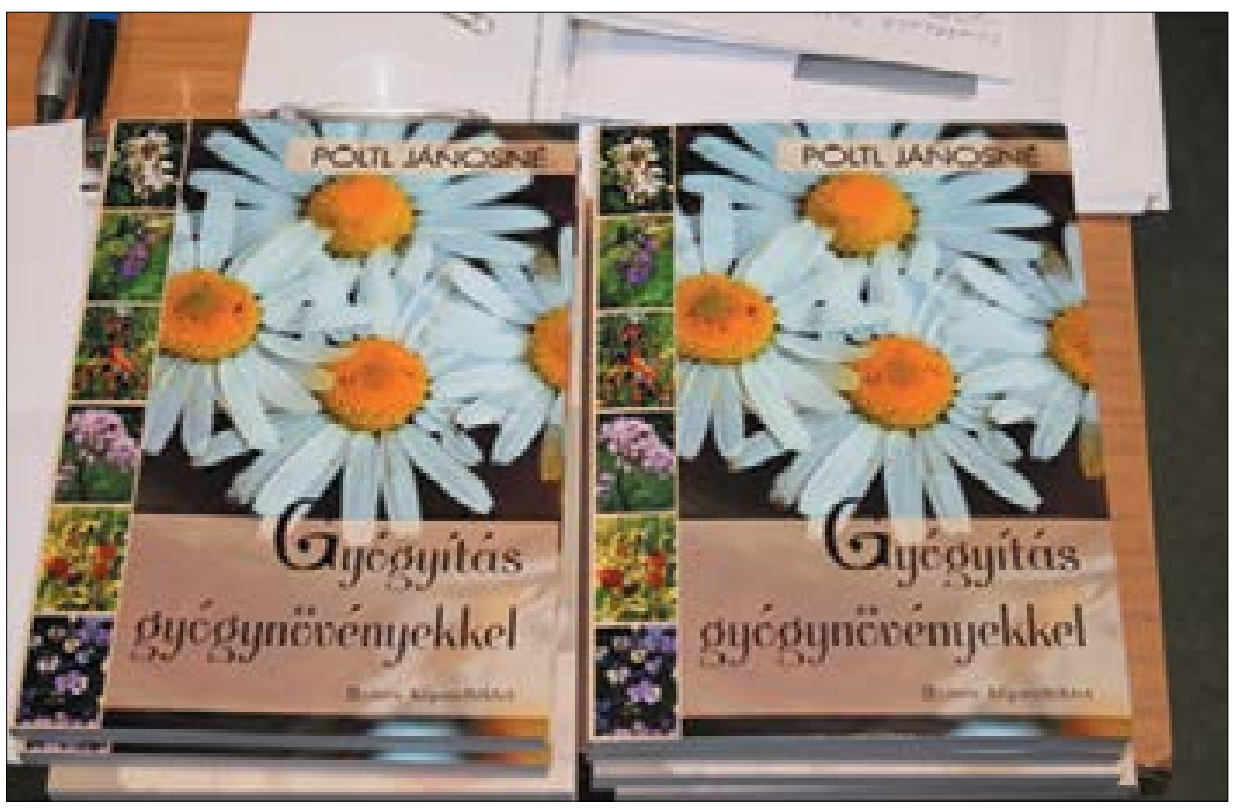

5. ábra. Egy könyvbemutató az Öko-esték sorozatunkban

\section{Ökotáborok (2013-)}

A könyvtár 2013-ban Agostyán-Ágostonligeten, 2014-2015-ben és 2017-ben pedig Komárom-Koppánymonostoron táboroztatta pályázati forrásokból a tatabányai általános, és részben középiskolás tanulókat. 2016-ban Bajnán az Alkotóházban is sikeres tábort tartottunk. Gyermekkönyvtárunk környezetismereti táborai már évek óta népszerüek. Ökotáboraink megvalósítását jelentős részben a Nemzeti Kulturális Alap pályázatainak elnyerésével tudtuk megvalósítani. Táboraink nem titkolt célja egy a helyi fiatalokból álló környezetbarát, környezetvédő csapat szervezése, akik a könyvtárunk szolgáltatásain keresztül már sokkal jobban eligazodhatnak ezekben a témákban, és sokkal közvetlenebb vonzerővel bírhatnak a saját korosztályuk felé. A táborok visszatérő témái: a lakóhely, a régió, az ország és az adott hely természetei értékeinek bemutatása; a megújuló energiák felfedezése a négyelemü világunkon (tüz, víz, föld, levegő) keresztül; gyógynövényeink, környezeti értékeink; a megyei értéktár idevonatkozó felvételeinek felismerése; valamint nagy hangsúlyt fektetünk a tudatos vásárlásra, fogyasztásra és az internet célszerü és veszélytelen használatára. 


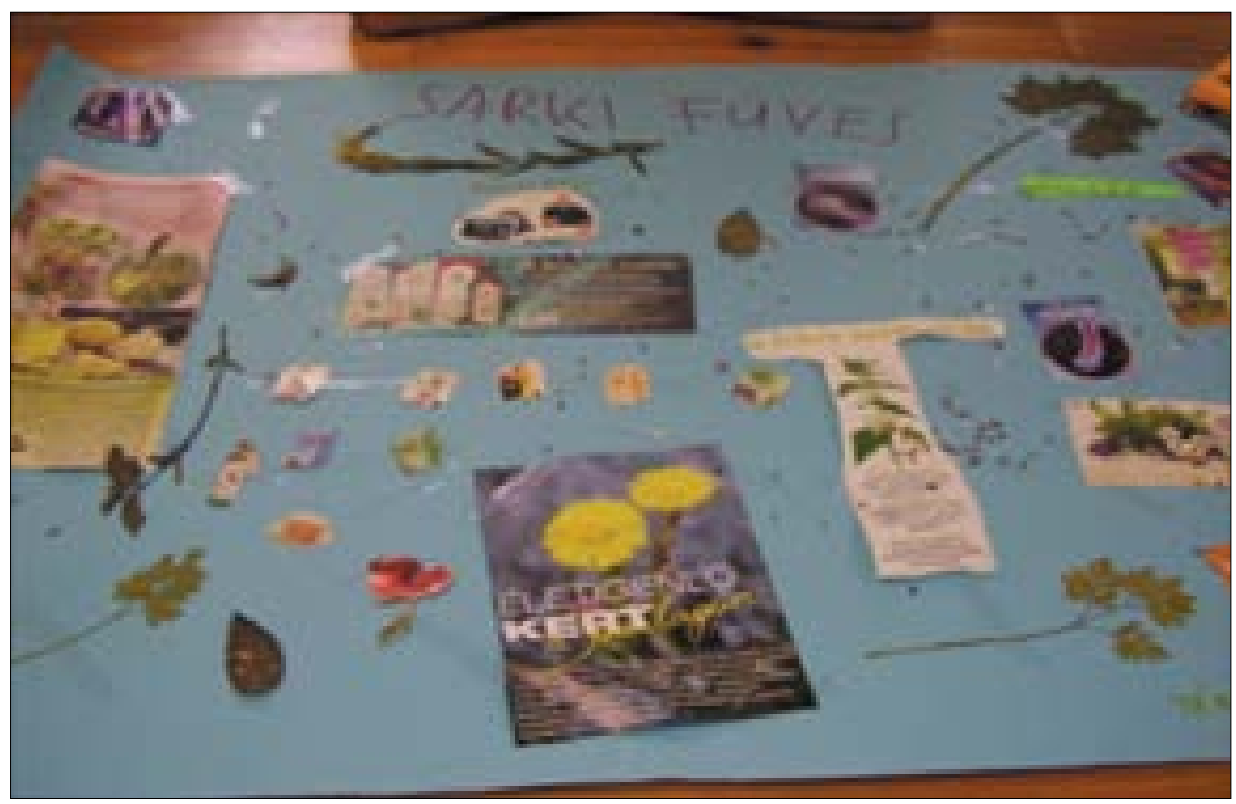

6. ábra. Koppánymonostor, 2014. A gyermekek gyógynövényboltja

\section{Zöld olvasóterem / Ökoterasz (2012-)}

2012-től várja az olvasókat a könyvtár hátsó kertjében kialakított „zöld olvasóterem". A Béke parkra néző teraszon kellemes, csendes környezet várja a látogatókat minden év májusától szeptemberig. A jó időt kihasználva nyaranta számos foglalkozást is tudunk itt tartani. A természetes környezetben évente több száz olvasónk veszi igénybe a szabadban olvasás lehetőségét.

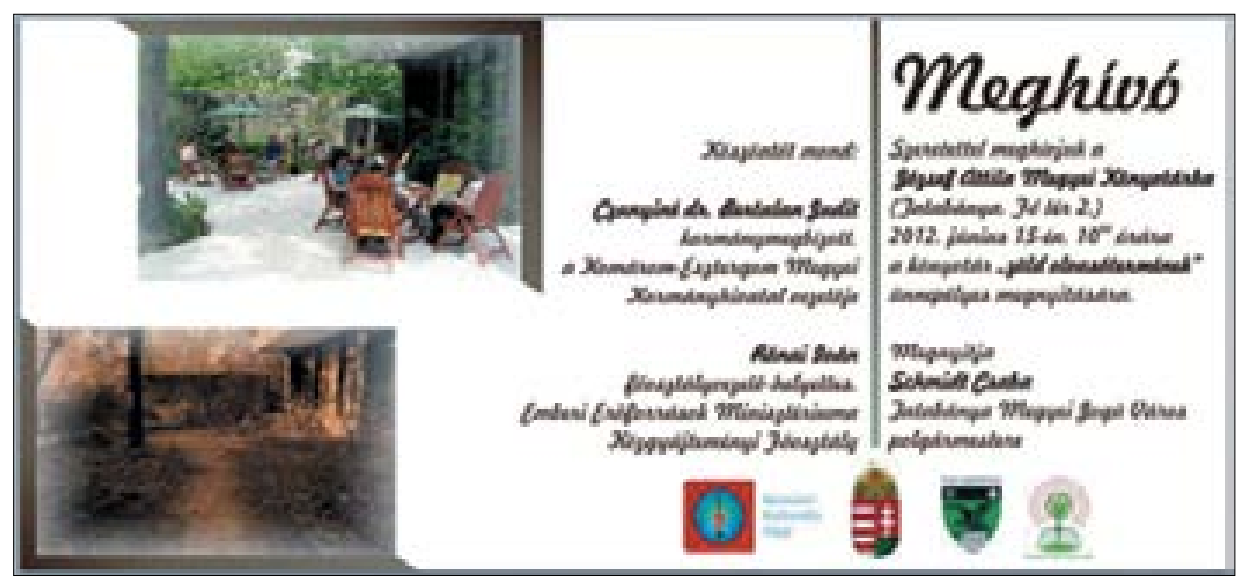

7. ábra. Terasznyitó, 2012. június 15. 


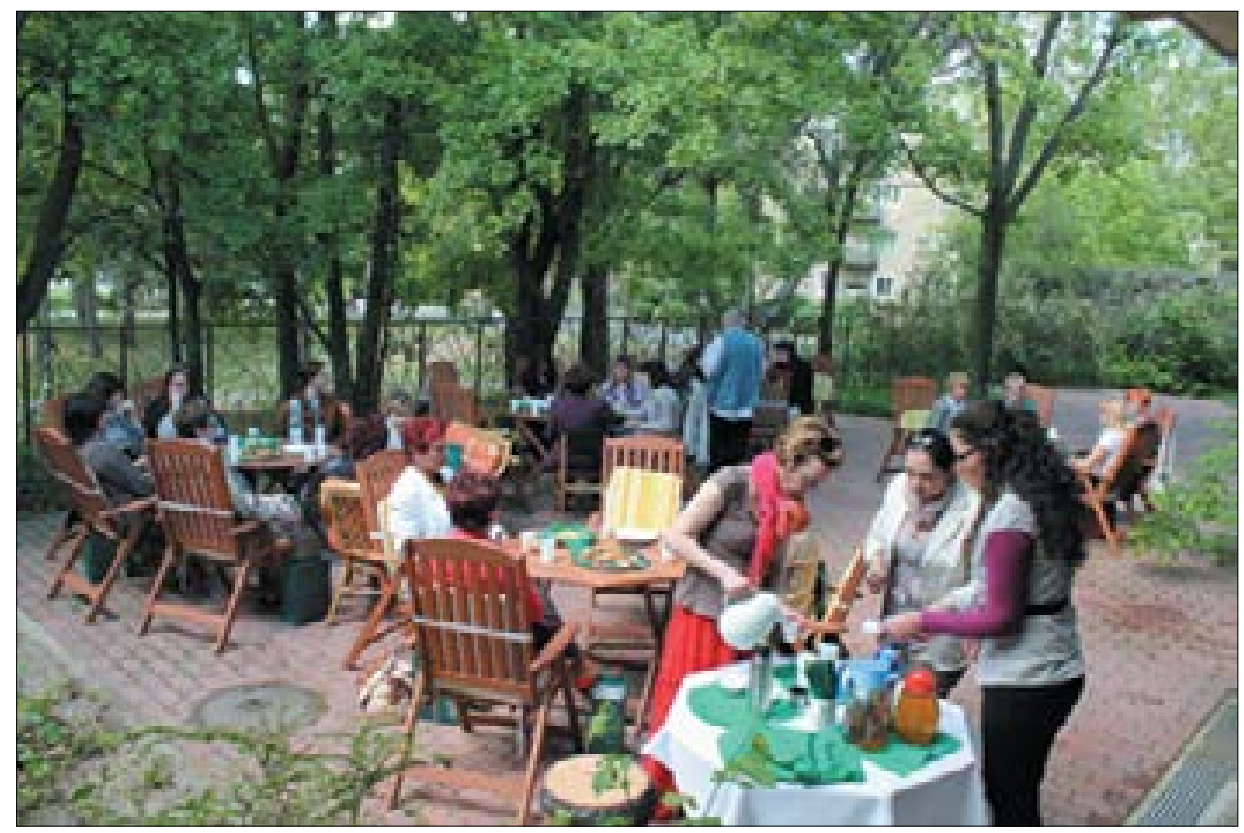

8. ábra. Határon túli kollégák látogatása, 2014. május 8. Életkép a zöld teraszon

\section{Zöldpolc-rendszer a könyvtárunk részlegeiben (2016-)}

2016 első félévének végén elkezdtük kialakítani városunk fiókkönyvtárainkban (Bánhida, Újváros, Felsőgalla, Kertváros, Óváros-Népház) egy úgynevezett zöldpolc-rendszert, amely tulajdonképpen egy kiemelés az adott fiókok állományából, ami a tágabban értelmezett ökológiai tárgykörből vett könyveket tartalmazza. A jövőben az újabb könyvkínálat rendeléseiből is ide kerülnek majd a természettel, környezetünkkel, fenntarthatósággal kapcsolatos kiadványok.

\section{Zöldpolc-rendszer kialakítása Kistérségi Könyvtárellátási Szolgáltató Rend- szerünk (KSZR) segítségével (2016-)}

Megyénk 59 olyan településének könyvtárát, amelyek a megyei könyvtártól rendelték meg az alapvető dokumentumbeszerzési, -feltárási, logisztikai, valamint a könyvtári környezet kialakítását célzó szolgáltatásokat, arra ösztönöztük, hogy - saját fiókkönyvtárainkhoz hasonlóan - egy közel egységes állományú, új beszerzésű, zöldpolc-rendszert alakítsanak ki, amellyel könyvtári eszközökkel erősíthetjük az adott települések környezettudatosságát. Ebben 2016 nyaráig 15 településnél tettük meg az első lépéseket, és azóta már egyre több településnél is „,bezöldülünk”. 


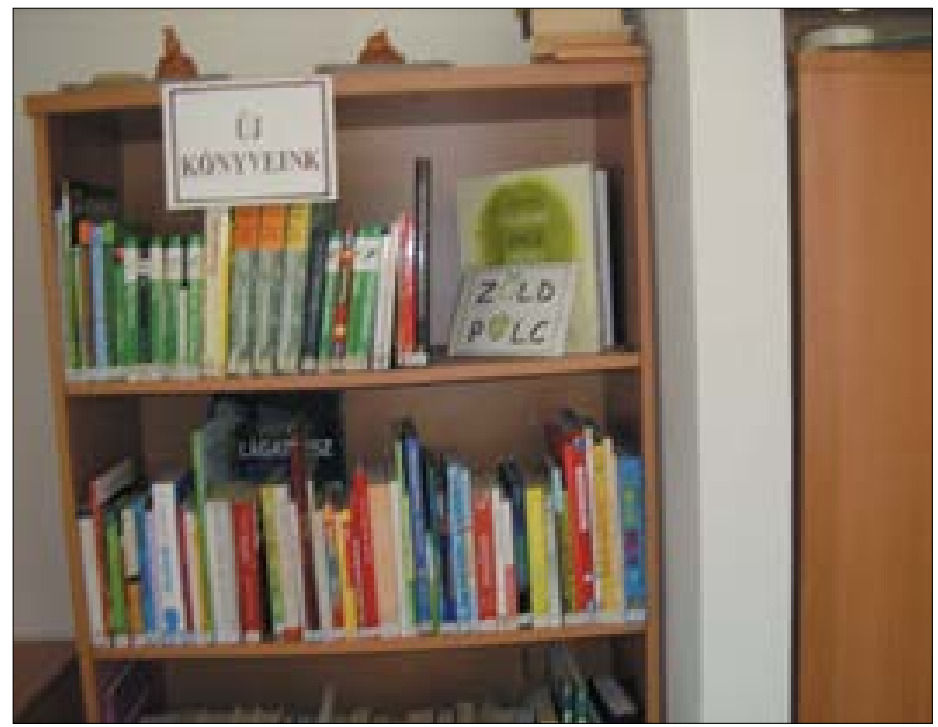

9. ábra. Zöldpolc Naszályon

2017. május 29-én Bajnán, az Alkotóházban a községi önkormányzat és a helyi könyvtár szervezésében a Gerecse titkai címmel környezetvédelmi vetélkedőt tartottak a helyi általános iskolások részvételével. Erre a nevezetes eseményre a József Attila Megyei és Városi Könyvtár részéről Nász János ökológiai szaktájékoztató kapott meghívást, hogy tudásával, tapasztalataival segítse a zsüri munkáját.

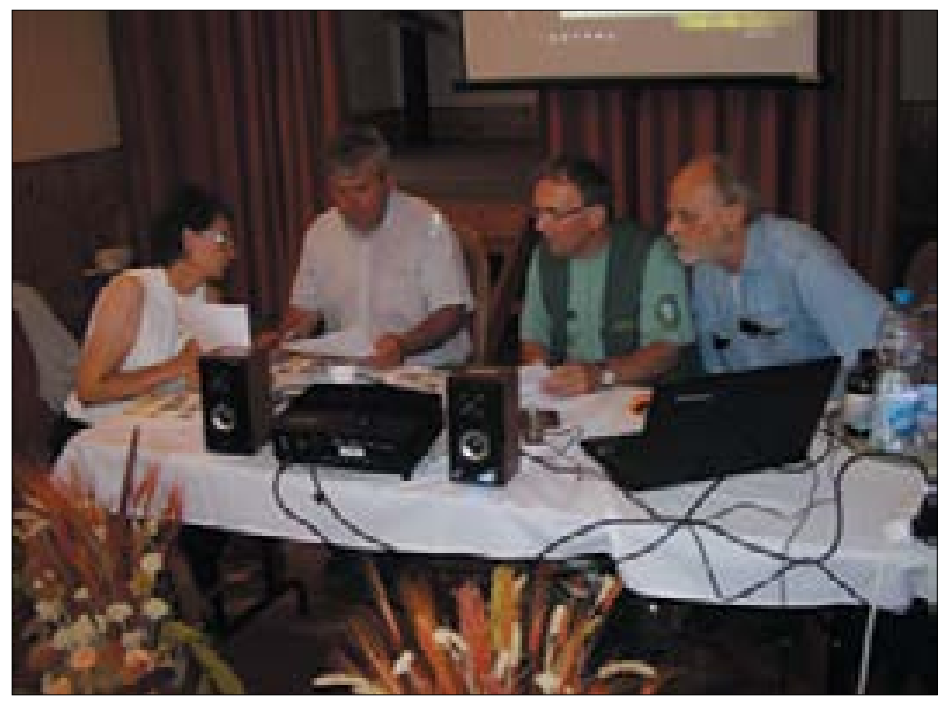

10. ábra. 2017. május 29., Bajna. A Gerecse titkai környezetismereti vetélkedő zsürijében 


\section{Részvétel a városunk öko-nagyrendezvényein (2014-)}

Könyvtárunk már évek óta kitelepül városunk öko-nagyrendezvényeire, ahol sokszínüen, játékos formában bemutatja saját könyvtári szolgáltatásait és környezettudatosító tevékenységét. Többek között a Nyitott Kapuk és a Környezetvédelmi Világnap rendezvényein is jelen vagyunk. Ezeken a rendezvényeken a városunk szolgáltatói mutatkoznak be. Közös célunk a fenntartónkkal az, hogy a településünkben tanulók óvodáskortól a középiskolás korig ismerjék meg azt, hogy milyen tevékenységek és szolgáltatások állnak rendelkezésükre a városukban, ezzel is erősítve az egészséges lokálpatriotizmust, ahogy itt mondjuk, a „tatabányaiság” érzését.

\section{Könyvtári ökopályázatok, online vetélkedők (2016-)}

Az online környezetismereti-környezetvédelmi pályázatunkat 2016 és 2017 októberében az Országos Könyvtári Napok keretében a helyi tatabányai és a kistérségek iskoláinak írtuk ki. A vetélkedő kérdéseit hírlevelünk, ökofüzetünk, sajtóbibliográfiánk, katalógusunk használata és a honlapunk alapján tettük fel, valamint fotópályázatot hirdettünk Tatabánya és közvetlen környéke környezetvédelmének témájában. TÉT-Tégy Érte Többet! címmel környezeti értékeinket bemutató fotópályázattal az iskolás korosztályt céloztuk meg.
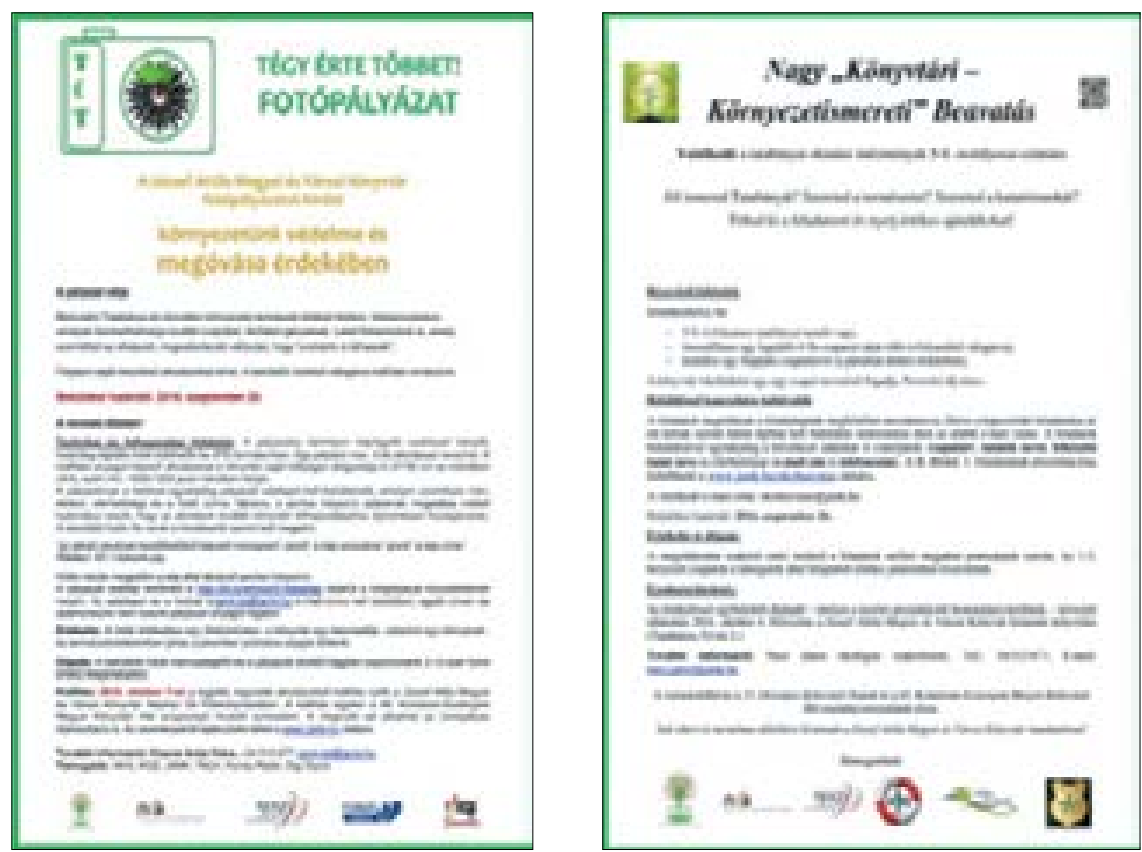


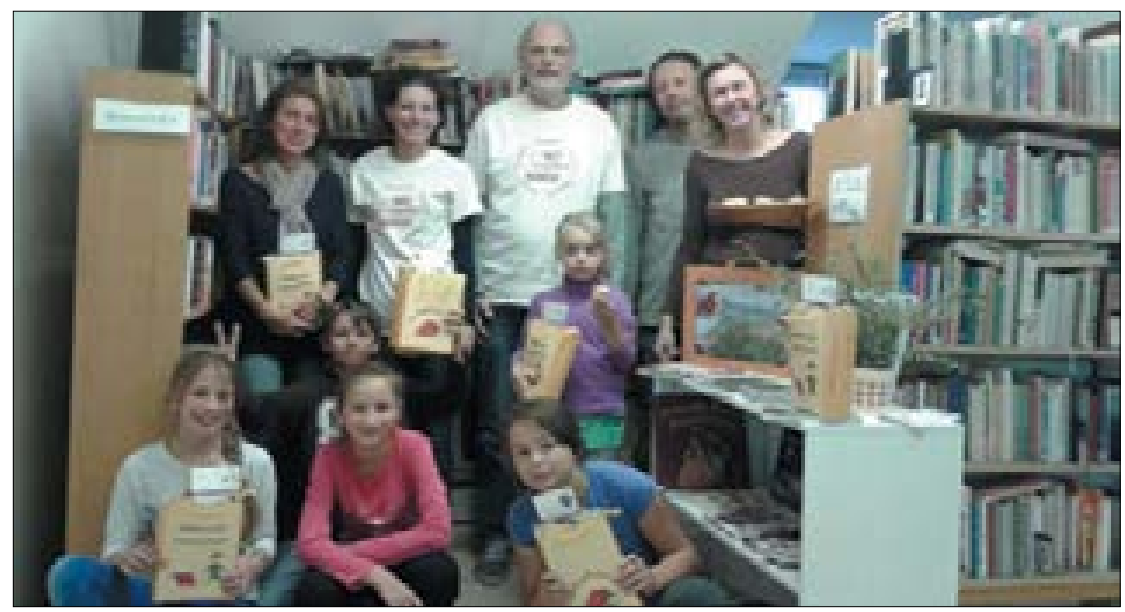

11. ábra. 2016. október 7., Vértesszőlős. A KSZR online ökovetélkedő döntője

\section{Gyermekrészlegünk környezettudatosító munkájáról}

A gyermekkönyvtár is nagy hangsúlyt fektet a környezetvédelemi, ökológiai nevelés széles körben való terjesztésére, mind rendezvényeit, mind müködését tekintve. Az elmúlt hét év eseményei közül a legfontosabbak: az óvodás, kisiskolás korosztály, és a sajátos nevelési igényü fiatalok számára tartott játékos interaktív foglalkozások, témanapok, táborok, pályázatok és az ökohét megszervezése. Évente a több mint 200 foglalkozásuk legtöbbjében központi téma a környezettudatosság, a környezetvédelem.

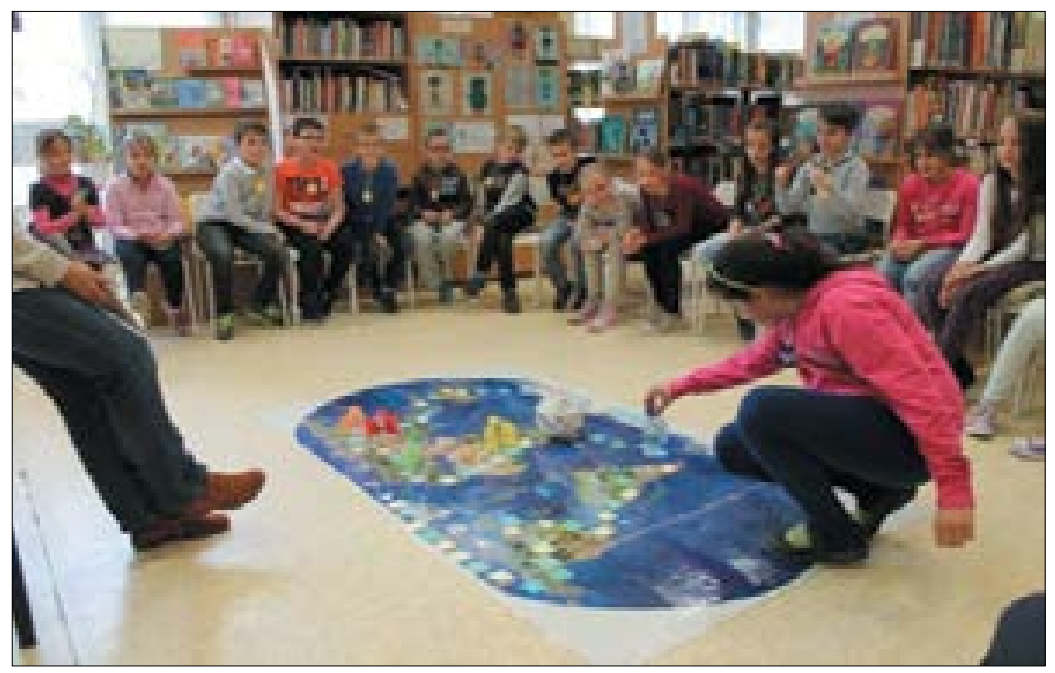

12. ábra. Mentsük meg Glóbit! ökotársasjáték 


\section{A gyermekkönyvtár ökotevékenységeiröl ${ }^{3}$}

2014 nyarától évente sikeresen részt veszünk a városi környezeti nevelési pályázatokon. Így jöttek létre Barangoló címü táboraink, melyek fő célja Tatabánya város értékeinek feltérképezése környezettudatos szemmel. A háromnapos napközis tábor programjának összeállításánál fő szempont a természetvédelem és a kézmüves foglalkozásink alapanyagai is a természetből valók. Ahová csak tehettük, kerékpárral és gyalogosan közlekedünk. A délutáni könyvtári elfoglaltságaink között első helyen szerepel a kézmüves foglalkozás, természetesen az újrahasznosítás és a környezetvédelem jegyében.

Egész hetes, bentlakásos, ismeretterjesztő táboraink minden évben egy adott téma körül csoportosulnak. 2015-ben a „természetismeret” volt a célunk, túrázással, állatbemutatóval, a Vértes természeti értékeinek bemutatásával. Helyszínül a közeli Környebányai Erdei Iskolát választottuk.

2013-ban több turnusban táboroztattunk a Boglártanya Erdei Iskolában, a Pro-Vértes Természetvédelmi Közalapítvány vendégeiként. Tanulóink nemcsak a közeli erdők-mezők állat- és növényvilágával kerültek barátságba, hanem minden nap részt vehettek a háziállatok gondozásában is.

A 2016. évi tavasz is az ökológiai gondolkodás jegyében telt: Ökohetet rendeztünk óvodások és kisiskolások számára. Mentsük meg Glóbit! címmel környezetvédelmi játékos foglalkozássorozattal vártuk a hozzánk érkező csoportokat, amiről a Magyar Televízió is tudósított. Természetesen maga a Gyermeknap is az ökoszemlélet jegyében zajlott, többek között ökomesék, ökojátszóház, ökoszöszmötölő, öko kézműves foglalkozások is színesítették. Mindezek mellett a gyermekkönyvtár egyéb tevékenységeiben is megnyilvánul a természetvédelmi gondolkodás. Nagyon fontos szerepet kap ugyanis a kézmüvesség az olvasásra nevelés kapcsán. Minden könyvtári foglalkozást, legyen az könyvtárbemutató vagy tematikus, illetve Papírszínház, szöszmötöléssel zárunk, segítve ezzel az elhangzottak komplex formában való „tálalását” a résztvevők számára. Ezen tevékenységek során, valamint az egész nyáron át tartó „Szerdai szöszmötölőkön" indirekt formában tanulják meg és alkalmazzák a gyerekek a gazdaságosság, a takarékosság, az újrahasznosítás fogalmait, természetesen más, hasznos ismeretekkel együtt.

Amellett, hogy a külső közönség számára közvetítjük ezt a szemléletmódot, kollégáink körében is egyre népszerübbé tesszük a szelektív hulladékgyüjtést, hiszen a gyermekkönyvtár minden újrahasznosítható dolgot befogad a WC papír gurigájától a parafa dugóig.

\footnotetext{
${ }^{3}$ A gyermekkönyvtári összefoglalót Erősné Suller Ildikó, a gyermekrészleg vezetője készítette.
} 


\section{Ökokapcsolatok}

A megyei könyvtár állandó meghívott a Klímabarát Települések Szövetsége, valamint a Magyar Tudományos Akadémia és a Magyar Szociológiai Társaság Holisztikus Ökológiai Szakosztálya ökokonferenciáin, rendezvényein. Gyümölcsöző, egymást támogató kapcsolat alakult ki a Tatabányai Klímakör Közhasznú Egyesülettel és a Vértesi Erdő Zrt.-vel is.

Örömteli, hogy egyre több hazai és határon túli könyvtár is érdeklődik a tatabányai könyvtár ökotevékenységéről. A saját és az országos, sőt a szlovákiai könyvtári sajtóban is, valamint a médiában számos tudósítás szólt az ez irányú rendezvényekről, valamint azokról az eseményekről, ahol meghívottak voltunk.

2015. április 13-án az érsekújvári Anton Bernolák családi-városi könyvtár meghívására és képviseletében előbb Érsekújváron egy baráti találkozó keretében, majd nyár elején, Zsolnán és Rajecfürdőn (június 16-17.) kétnapos nemzetközi könyvtáros konferencián vehettünk részt, ahol bemutattuk könyvtárunk ökotevékenységét. 2017-ben a Nyitrai Karol Kmetko Kerületi Könyvtárban, V4-es körben, lengyel, szlovák, magyar részvétellel mutatkoztunk be egy lehetséges közös projekt teveinek keretében.

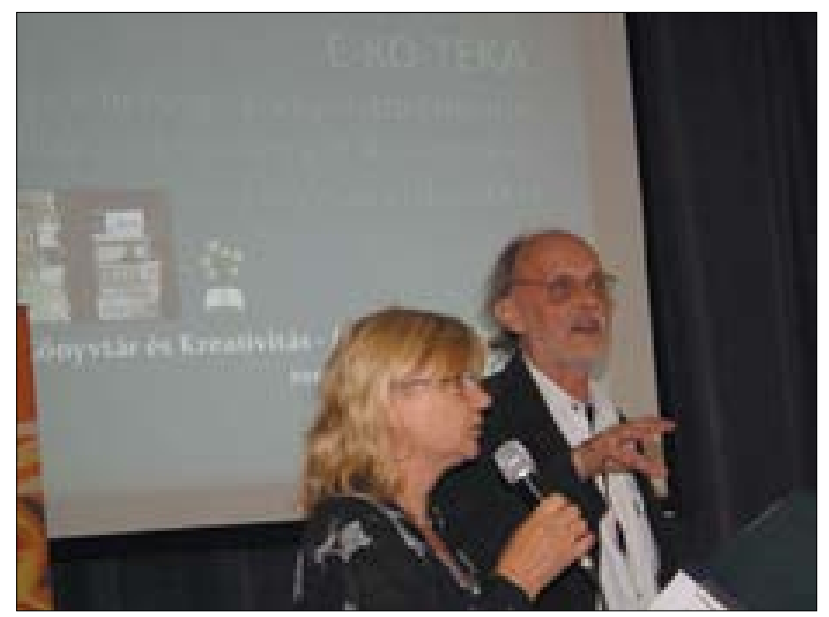

13. ábra. 2015. június 16-17., Zsolna. Rajecfürdő ökoprezentáció

2017 áprilisában a Komárom-Esztergom megyei éghajlatváltozási platform a klímaváltozással és a klímaváltozás hatásaihoz való alkalmazkodás érdekében egy pályázat keretében meghívta tagjai közé könyvtárunkat, hogy legyünk segítségükre a hamarosan megjelenő, a települési klímastratégiák elkészítését célzó KEHOP 1.2.1 pályázat megvalósításában.

2017. június 9-én, a Környezetvédelmi Világnapon, egy meghívás alapján a Komáromi Jókai Mór Városi Könyvtár gyermekrészlegében 30 kisiskolás és ta- 
náraik részvételével közösen megtekintették a Vad Magyarország - A vizek birodalma című filmet (amely egyébként Könyvtármozis film is), és játékos formában feldolgozták az ott látottakat. A film a legfontosabb hazai tájainkat mutatta be az állat- és növényvilágon keresztül az évszakok változásában. Nyelvi játékokon, fejtörőken keresztül az élővilággal kapcsolatban hívtuk fel a figyelmet hazánk természeti értékeire és a környezetünk megóvására.

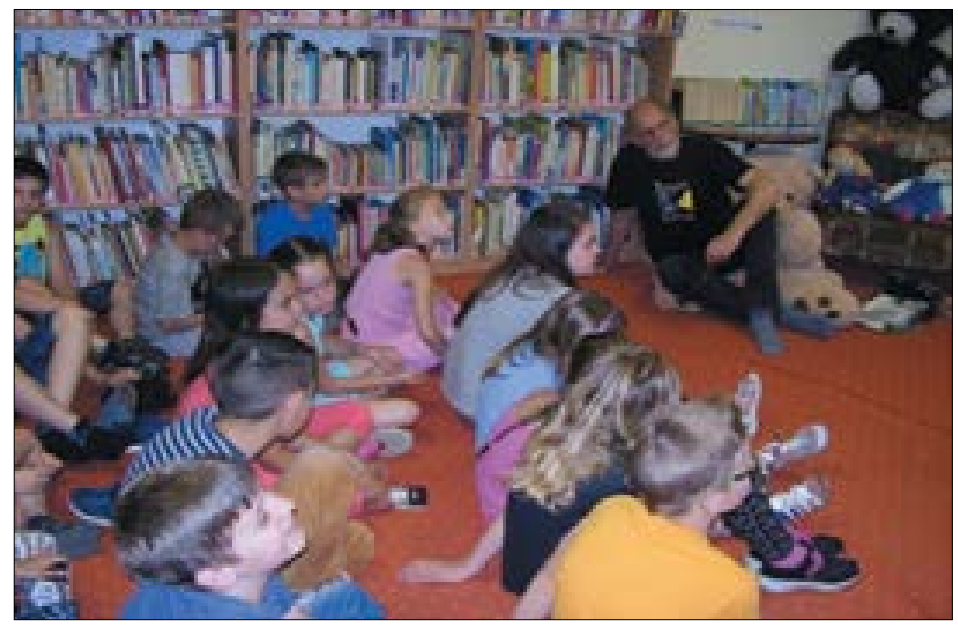

14. ábra. Környezetvédelmi Világnap, 2017. június 9., Komárom Jókai Mór Városi Könyvtár gyermekkönyvtára

Ide sorolhatnánk még számos előadásunkat, prezentációnkat, megjelenésünket a szaksajtóban a könyvtárunk tevékenységéröl, amelyeket nálunk és más honi és határon túli könyvtárakban tartottunk meg.

2015. április 13-án Érsekújváron az Anton Bernolak családi könyvtárban a Könyvtárosok Világnapja keretében mutatkoztunk meg először a könyvtárzöldítő tevékenységünkkel.

2015. június 16-17. között a szlovákiai közösségi könyvtárak évente megrendezett, Könyvtár - Közösség - Kreativitás konferenciáján, Zsolna-Rajecfürdőn, Nász János, a megyei könyvtár ökoarculatáért felelős munkatársa és az Öko-esték állandó házigazdája előadást tartott „E-KO-TEKA, azaz egy lehetséges környezettudatositási módszer (environmental awareness) könyvtári eszközökkel' címmel. Ez a meghívás jól példázza a határon túli kapcsolataink felé való elmozdulást. 2016. szeptember 14-én Tatabányán, a központi könyvtárunkban a Nyitra megyei könyvtárosoknak beszéltünk a József Attila Megyei és Városi Könyvtár ökológiai szemléletéről. 2016. szeptember 29-én Nyitrán, egy nemzetközi könyvtáros konferencián lengyel és szlovák kollégáinkat ösztönöztük egy esetleges V4-es projekt megvalósítására ebben a témában. 


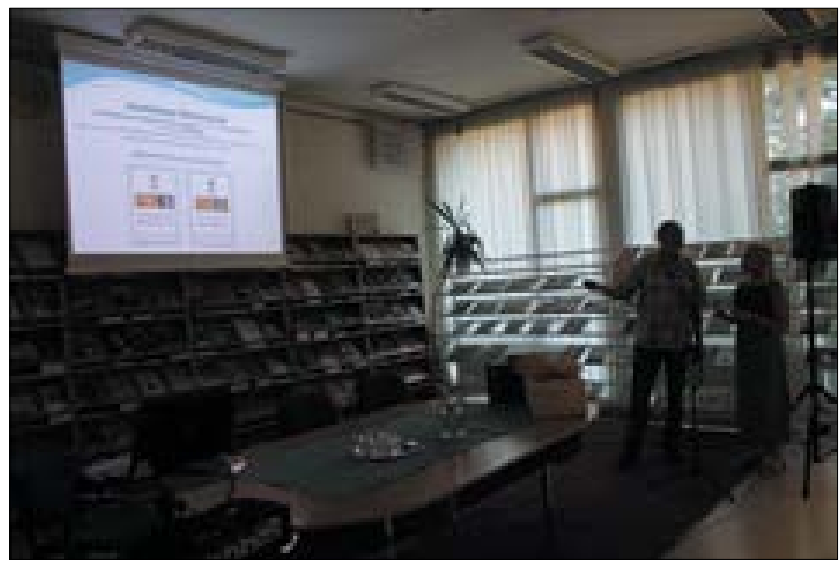

15. ábra. 2016. szeptember 14., Tatabánya. Szlovák-magyar szakmai találkozó

2016. október 3-án, a 45. Könyvtári Hét szakmai nap keretében ismertettük megyénk könyvtárosainak $A$ Zöld Könyvtár címü munkáinkat.

2017. március 31-én Tatabányán, az Árpád Szálló nagytermében: Ökoszemlélet és KönyvtárMozi címmel a KönyvtárMozi program keretében ajánlott ökofilmek bemutatásának tapasztalatairól adtunk számot.

2017. augusztus 31-én Budapesten, az ELTE Egyetemi Könyvtár és Levéltár központjában Könyvtárzöldités, avagy a József Attila Megyei és Könyvtár ökoskodásai a 2010-2017 közötti idöszakban címmel a Hagyományok és kihívások szakmai konferencia keretében nyilvánultunk meg.

2017 novemberében pedig meghívást kaptunk Nyíregyházára a SzabolcsSzatmár megyei Könyvtáros Egyesület konferenciájára zöld témáink bemutatására.

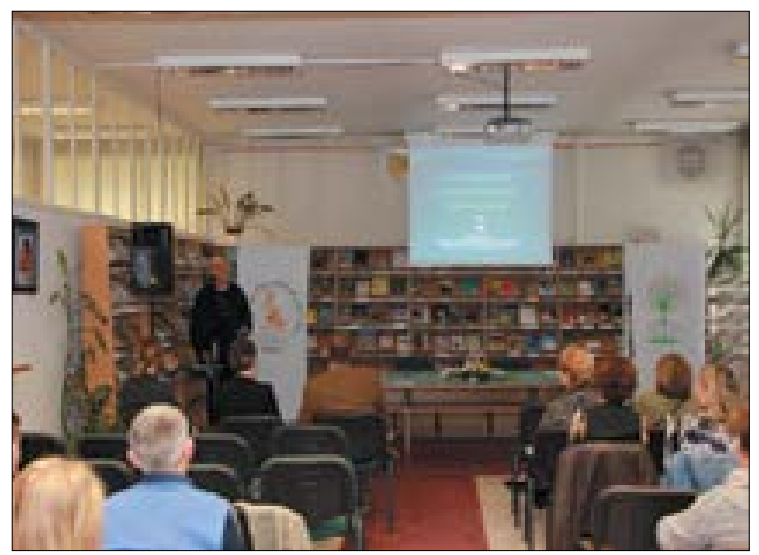

16. ábra. 2016. október 3., 45. Könyvtári Hét, Tatabánya JAMK.

A Zöld Könyvtár prezentáció 
A korábban már említett, ökofüzetünket teljes egészében közölte a könyvtári szaksajtó (1. Nász János - Nagy Ádám: Az ökológiai gondolkodás erősítése Tatabánya város lakóközösségében könyvtári eszközökkel. = Könyvtári Levelezőlap, 2016. 2. sz. 13-18. p.).

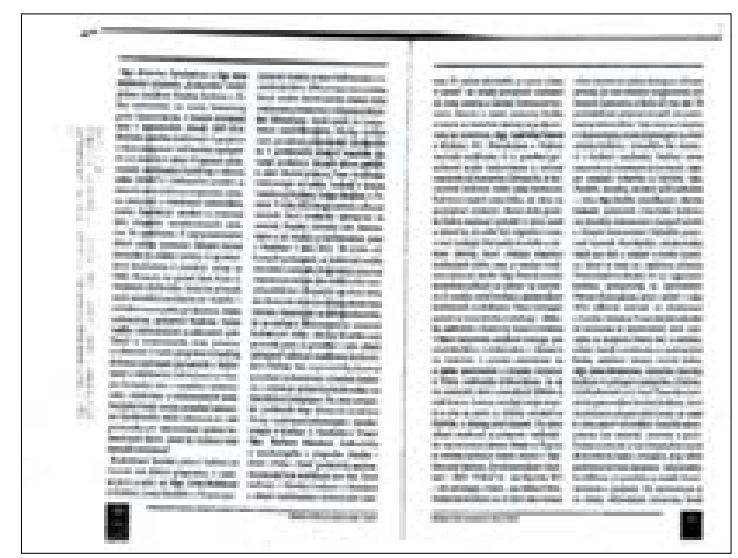

17. ábra. A szlovák könyvtáros sajtó a zsolnai konferenciáról szóló összefoglalójában ismerteti előadásunkat: Komunitná kniznica sa konala v Ziline. = Bulletin SAK, rocnik 23, cislo 3/2015. 41-47. p.

\section{Ökodolgaink a közszsolgálati televízióban}

A közszolgálati televízió két ízben is élő kapcsolattal tudósított ökodolgainkról.

1. 2016. május 11.: MTV1 Hiradója: dr. Voit Pál - Nász János: „Az ország első zöldkönyvtára lehet a tatabányai" (2016. 05. 11.) A teljes riport 3.43-tól látható: http://www.mediaklikk.hu/video/ma-delelott-2016-05-22-i-adas-3

2. 2016. május 22.: Az első gyermekkönyvtári Öko-hét: Mentsük meg a Glóbit „Ökogyereknapot rendeznek Tatabányán” (2016. 05. 22. - ÉLÖ). A teljes riport 17.21-től látható: http://www.mediaklikk.hu/video/ma-delutan-2016-0511-i-adas-2

\section{A KönyvtárMozi ökofilmjeinek bemutatása, felvezetése, beszélgetés a film- röl a KSZR kiskönyvtáraiban}

A magyar filmkultúra alapvető értékei az ország több mint 400 kistelepülési könyvtárában elérhető a KönyvtárMozi szolgáltatással. 2017-től megyénkben, 14 településen ökofilmek is bemutatásra kerülnek. A mozgalom nem titkolt célja az, hogy az 5000 lélekszám alatti településeken a könyvtárak kulturális közösségi otthonokká szerveződjenek. A bemutatott filmek akár indirekt módon a saját településükért felelösséget vállaló közösségé formálhatják az ott lakókat, valamint a helyi kis könyvtárakon keresztül elérhetővé válhat az egész magyar könyvtári szolgáltatásrendszer. 
A kínálatban két ökofilm is található. Ezek közül dr. Danka Krisztina: A természet IQ-ja a felnött közönségnek, míg a Török Zoltán: Vad Magyarország A vizek birodalma, az általános iskolai korosztálynak szólnak. A filmeket felvezetjük, játékos formában feldolgozzuk, majd beszélgetünk róluk (1. http:// konyvtarmozi.hu).
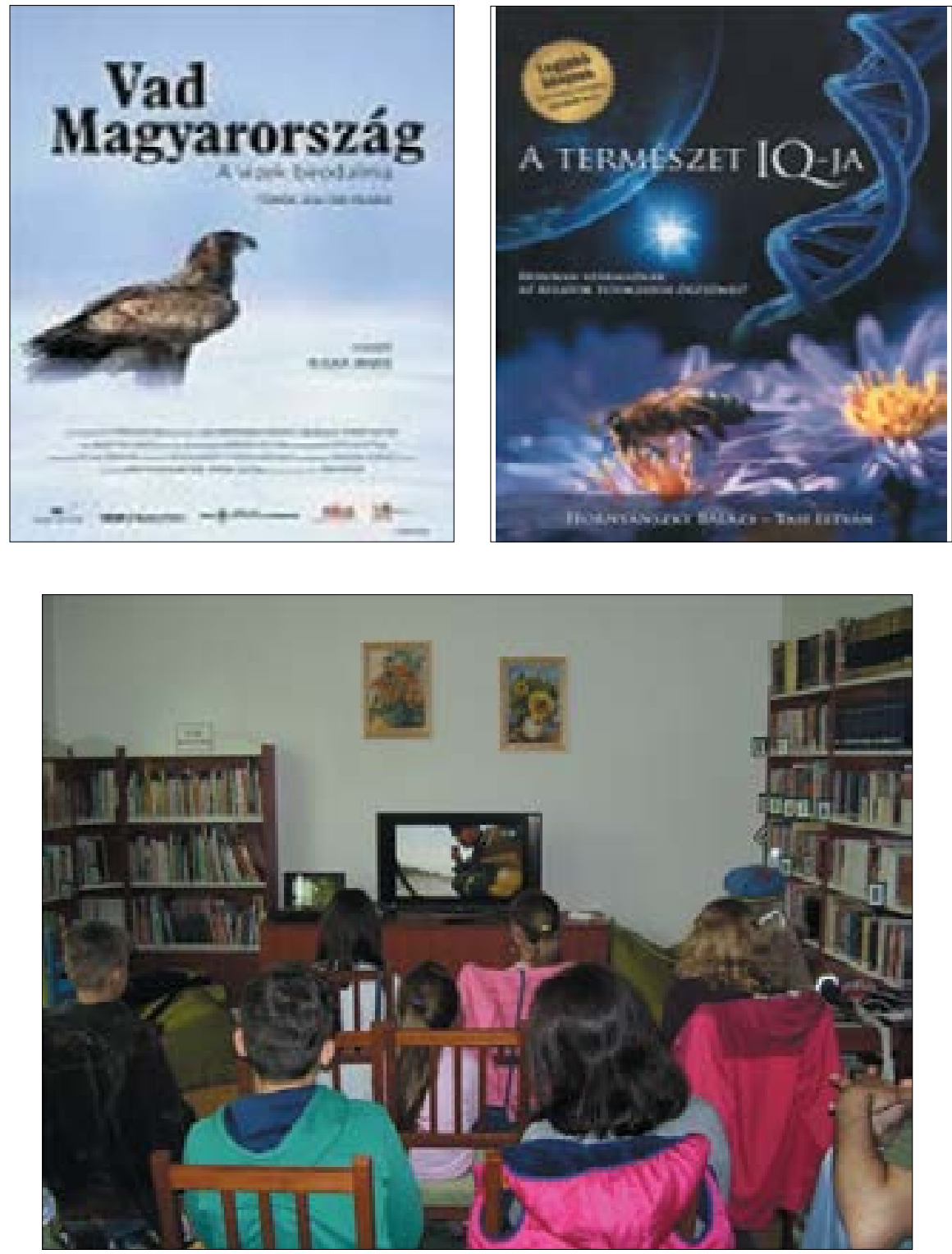

18. ábra. KönyvtárMozi ökofilmekkel, most éppen Dunaalmáson 


\section{A fenntartható jövő alapkövetelménye}

Be kell ruházni az oktatásba, a kultúrába, így a tudástárakba, a könyvtárakba is. A tudatosság a záloga egy szerethető, élhető és fenntartható világnak. A környezettudatosítás helyi szinten, helyi megoldásokkal, helyi példákkal a leghatékonyabb. A kihívásokra a holisztikus megközelítések adhatják a legjobb válaszokat, amelyek a társadalom minden rétegét képesek megszólítani.

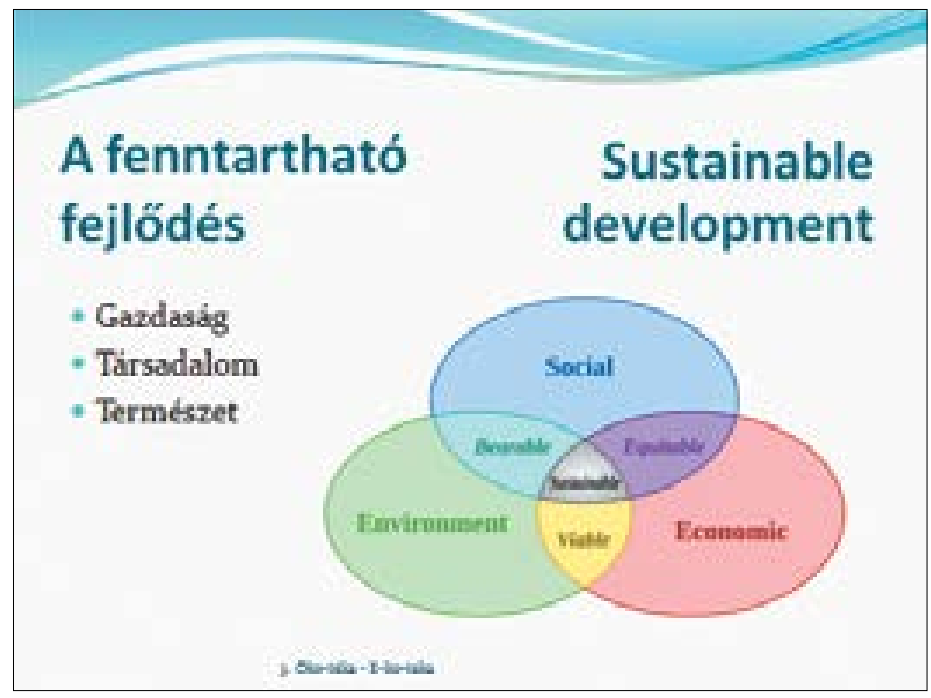

19. ábra. Azért, hogy a világunk elviselhető, igazságos, életképes, fenntartható lehessen

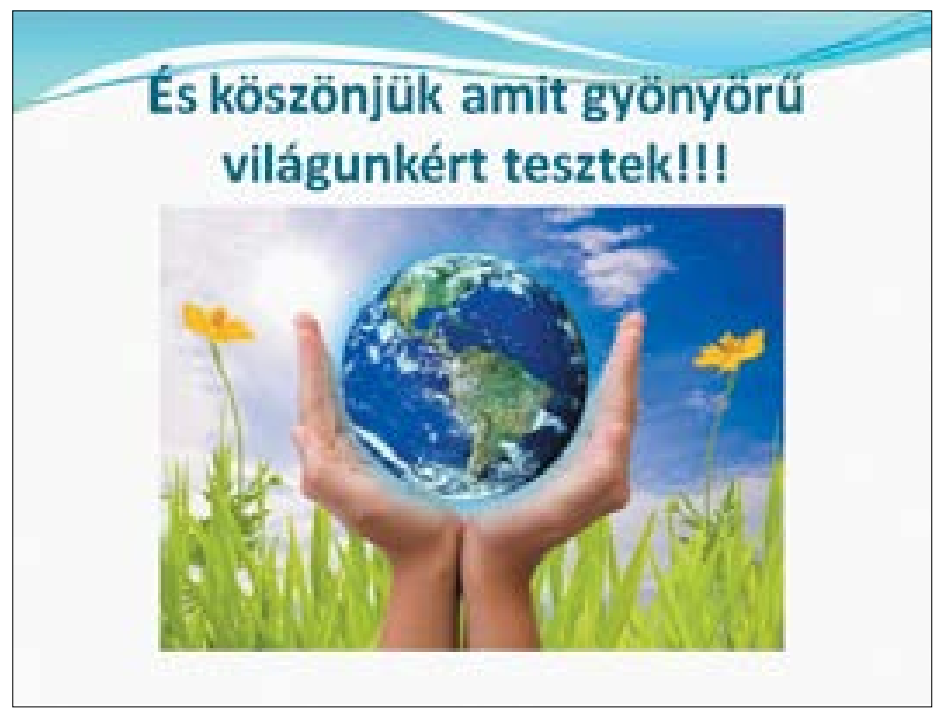




\section{Rezümé}

2010-ben a tatabányai József Attila Megyei és Városi Könyvtár dr. Voit Pál vezetésével a közösségi közművelödési könyvtárak közül elsőként emelte ki küldetésnyilatkozatában a fenntarthatóság és környezettudatosság szemléletét.

A környezettudatosításra széles körü érzékenyítés és a szemléletformálás e téren is feladatot ró a könyvtárakra. Ugyanakkor saját maguk hagyományos feladatrendszerét és szolgáltatásait is az új paradigma irányában kell mozdítaniuk.

A dolgozat áttekinti és dokumentálja azt a folyamatot, amint 2010 nyarától a tatabányai József Attila Megyei és Városi Könyvtár megkezdte kialakítani ökológiai gyüjteményét, tájékoztató részlegét és sokirányú információs szolgáltató rendszerét. Ökoszolgáltatásai és a 13 részterület bemutatása révén, valamint különböző célközönségeinek, illetve külső partnerhálózatának bővítésével bizonyítja, hogy hogyan alakítható ki könyvtári és nem könyvtári eszközök segítségével a városi és kistérségi, megyei hatókörön is túlmutató munka közös felelösségvállalása, a fenntarthatóságot szem elött tartó ökoszemlélet. A dolgozat példákon és az eddig elért eredményeken keresztül szemlélteti, hogy a közösségi-közmüvelödési-nyilvános könyvtárak (public library) - éppen a nyilvánosságuk miatt -miként lehetnek a helyi válaszok, intézkedések, személyes és akár intézményes példák gyors és közvetlen elindítói.

Mára már könyvtári és ökológiai szakértők által is megerősítést nyert, hogy a tatabányai könyvtár nyilvános, közművelődési zöld könyvtárként (public green library) mintaértékünek tekintik ökológiai elhivatottságát és tevékenységét. 2017-re kiterjesztette könyvtári zöldpolc-rendszerét városi fiókkönyvtár-hálózatára, továbbá a vele szolgáltatási szerzödést kötött települési könyvtárakra is Komárom-Esztergom megyében.

\section{Making a library green: shaping and raising environmental awareness by traditional and non-traditional library tools}

In 2010 the Attila József City and County Library, Tatabánya, Hungary, lead by Pál Voit, was the first to emphasize sustainability and environmental awareness in its mission statement

Libraries have tasks to do in the field of sensitization for environmental awareness and altering attitudes and approaches. However, they have to reshape their traditional tasks and services according to this new paradigm.

The paper offers an overview and a documentation of this process which started with the foundation of an ecology collection and reference unit in the summer of 2010 at the Attila József City and County Library, and has lead to the development of a system of ecology related information services. Its ecoservices and 13 different activities are presented. The library has broadened its target audience as well as its network of external partners, and applied library and non-library tools in order to prove that a joint responsibility and a sustainability focused eco-approach may be manifested in the cooperation which goes over the boundaries of the county. Good practices and achievements dem- 
onstrate that public libraries - right because they are public - may initiate and facilitate rapidly and directly local solutions, actions, personal or institutional examples.

At present both library and ecology experts have confirmed that the ecological dedication and activities of the Tatabánya green public library serve as a model for others. In 2017 the library has opened green shelves in its branch libraries all over the town, and in village libraries around Komárom-Esztergom county which have a service provision contract with the county library.

NÁSZ JÁNOS

ökológiai szaktájékoztató

József Attila Megyei és Városi Könyvtár, Tatabánya 